\title{
Cardiovascular health education intervention in the Prison of Soria
}

\author{
MM Martínez-Delgado1, C Ramírez-López ${ }^{2}$
}

${ }^{1}$ Nurse at the Prison of Soria

${ }^{2} 4$ th Year Nursing Student from Soria University Nursing

\begin{abstract}
Objective: To promote awareness of healthy lifestyles, to help decrease the risk factors that cause cardiovascular disease, obesity, diabetes, hypertension and hyperlipidemia, through Health Education (HE).

Material and Methods: Between November and December 2014 in the prison of Soria, HE intervention in cardiovascular diseases was performed. Participation was offered to 160 inmates at the Prison. The intervention consisted of individual interviews with anthropometric assessment and review of medical records and three group sessions with theoretical and practical content of these diseases, as well as dietary recommendations, Mediterranean diet and exercise. Knowledge gained from surveys conducted for that purpose was evaluated.

Results: A total of $33(21 \%)$ of 160 . Average age 38.2 (35.2 to 41.3). Prevalence: Normal weight (BMI 18 to 24.9$) 18$ (54.5\%), overweight BMI (25.0 to 29.9) 11 (33.3\%), obesity (IBMI from 30) 4 (12. 1\%). Cardiovascular risk (CVR) as ICC (waist hip ratio) $10(30 \%)$ high risk, REGICOR $4(12.1 \%)$ moderate risk. Relative risk of comorbidity in 2 (6.0\%) had a slightly increased risk, $4(12.1 \%)$ had increased risk. Conclusions: HE interventions are necessary and effective in modifying lifestyles. The calculation of CVT should serve to implement preventive measures to reduce the factors of cardiovascular risk.
\end{abstract}

Keywords: Prisons; Health Education; Cardiovascular agents; Diabetes mellitus; Obesity; Hypertension; Lifestyle; Feeding; Exercise; Comorbidity

Text received: 23/03/2015

Text accepted: 20/08/2015

\section{INTRODUCTION}

According to the Ottawa Charter, Health Promotion is the process of enabling people to increase control over, and to improve, their health. Health promotion mainly entails actions intended for addressing all potentially modifiable health determinants. Health Education is a key part of health promotion and according to the World Health Organization (WHO), it includes any combination of learning experiences designed to help individuals and communities improve their health by increasing their knowledge or influencing their attitudes ${ }^{1-4}$.

The Spanish Society for the Study of Obesity (SEEDO) in its 2007 General Agreement as well as the WHO, consider that obesity has become the second avoidable cause of premature death worldwide, after smoking, and that it is directly associated with cardiovascular diseases ${ }^{5}$.

According to a study carried out by GESESP (the Nursing Group of the Spanish Society for Prison Health) on the prevalence of chronic diseases within correctional facilities, it has been proved that chronic diseases have now replaced infectious diseases as the leading cause of death among the imprisoned population, as well as within the general public ${ }^{6,7}$. Several studies reveal that the imprisoned population is now an ageing population, overweight in a significant percentage and with a high prevalence of lifestyle related diseases $^{8,9}$. This justifies that one of the main issues included in health education interventions in prisons are lifestyle related diseases. We must consider that the level of health among a determined population is directly associated with its educational, social 
and economical level, and therefore health education interventions should be aimed at the specific health needs of that population according to their previous knowledge on the issue ${ }^{10-11}$. The special nature of the imprisoned population makes health interventions necessary and essential.

There are several tools that allow assessing the relative risk of developing obesity related comorbid conditions such as the aforementioned diseases: diabetes, hypertension (HT), etc. These tools mainly consist of jointly considering obesity and the body distribution of adipose tissue through different anthropometric measures such as Quetelet index or BMI (body mass index), WHR (waist-to-hip ratio) or WC (waist circumference), which has been acknowledged in several studies as a cardiovascular risk predictor and indicator ${ }^{12-13}$. Other tools estimate an individual's overall cardiovascular risk, among others: Framingham risk score, REGICOR or SCORE. The assessment of cardiovascular risk (CVR) should serve for the implementation of preventive measures aimed at reducing risk factors, and therefore have a significant guidance value $\mathrm{e}^{14-16}$

The current development of prison nursing includes several roles such as the provision of healthcare, teaching, research and management. Teaching itself can be developed in two different directions. On one hand, it can be aimed at promoting self-care among inmates through Health Education strategies and on the other hand, Nursing has its own body of knowledge which needs to be transmitted in training new professionals ${ }^{17}$. This project includes both. The correctional institution of Soria cooperates with the University of Valladolid in training pre-graduate students and offers internships for fourth year nursing students. These students have actively taken part in the development of Health Education projects such as the present.

\section{MAIN OBJECTIVE}

To promote lifestyle changes that will lead to the reduction of risk factors associated with the development of cardiovascular diseases, diabetes, hypertension and dyslipidemia.

\section{SPECIFIC OBJECTIVES}

- To provide enhanced knowledge on cardiovascular disease predisposing chronic conditions.

- To enhance healthy habits related to eating and physical exercise.
- To assess individual risk of cardiovascular or predisposing diseases trough anthropometric evaluation.

- To raise awareness on the need of Health Education interventions among new nursing staff.

\section{MATERIAL AND METHODS}

Descriptive study on a community intervention carried out in the correctional institution of Soria throughout November and December 2014. The sample was selected by offering voluntary participation to all inmates hosted in November 2014 in the institution (160 inmates). Information was provided by signboards distributed in all prison facilities. Nursing staff were also a fundamental resource of information by recommending inmates suffering from some kind of condition, such as hypertension or diabetes, to participate. 33 out of 160 inmates hosted at the time signed up for the intervention. The intervention included four sessions: the first was an individual interview and the rest implied group work. A final assessment of the knowledge gained and of the intervention itself was performed by means of a so purposed questionnaire.

In the first session interviewers took anthropometric measurements such as weight $(\mathrm{kg})$, height $(\mathrm{cm})$, waist circumference $(\mathrm{cm})$, hip circumference $(\mathrm{cm})$ and blood pressure BP (mmHg). A calibrated SOEHNLE digital scale with an incorporated stadiometer and an elastic tape were used to take measurements. To measure the waist circumference, inmates were asked to stand naked while the middle point between the edge of the rib and the iliac crest was located and the waist was surrounded at that point. For the hip circumference, greater trochanters were used as the reference for the measurement. Blood pressure was taken with a digital OMRON monitor, properly calibrated. Two consecutive measurements of blood pressure were taken within a five-minute period and the mean value was obtained. Through Quetelet's index, BMI was calculated, which despite not being the best indicator of adiposity in highly worked-out, athletic or senior individuals, is the index used in most epidemiological studies and thus, recommended by different medical associations. By means of Bray and Gray's scale (1988) (Anthropometric Standardization Reference Manual) cardiovascular risk was assessed as associated to age, gender and WHR (see Table1). Obesity's relative risk of suffering other conditions such as diabetes, hypertension and other cardiovascular diseases was calculated by correlating BMI and the waist circumference (see Table 2). Inmates were questioned on habits such 
Table 1: Cardiovascular risk assessment according to Age and the Waist-to-Hip Ratio, as assessed by Gray and Bray's scale (Anthropometric Standardization Reference Manual).

\begin{tabular}{|c|c|c|c|c|}
\hline MALE: & \multicolumn{4}{|c|}{ RISK: } \\
\hline Age Groups & LOW & MODERATE & HIGH & VERY HIGH \\
\hline $20-29$ & $<0.83$ & $0.83-0.88$ & $0.89-0.94$ & $>0.94$ \\
\hline $30-39$ & $<0.84$ & $0.84-0.91$ & $0.92-0.96$ & $>0.96$ \\
\hline $40-49$ & $<0.88$ & $0.88-0.95$ & $0.96-1.00$ & $>1$ \\
\hline $50-59$ & $<0.90$ & $0.90-0.96$ & $0.97-1.02$ & $>1.02$ \\
\hline $60-69$ & $<0.91$ & $0.91-0.98$ & $0.99-1.03$ & $>1.03$ \\
\hline FEMALE: & \multicolumn{4}{|c|}{ RIESK: } \\
\hline Age Groups & LOW & MODERATE & HIGH & VERY HIGH \\
\hline $20-29$ & $<0.71$ & $0.71-0.77$ & $0.78-0.82$ & $>0.82$ \\
\hline $30-39$ & $<0.72$ & $0.72-0.78$ & $0.79-0.84$ & $>0.84$ \\
\hline $40-49$ & $<0.73$ & $0.73-0.79$ & $0.80-0.87$ & $>0.87$ \\
\hline $50-59$ & $<0.74$ & $0.74-0.81$ & $0.82-0.88$ & $>0.88$ \\
\hline $60-69$ & $<0.76$ & $0.76-0.83$ & $0.84-0.90$ & $>0.90$ \\
\hline
\end{tabular}

Table 2: Main quantitative variables analyzed.

\begin{tabular}{|c|c|c|c|c|}
\hline VARIABLES & MEAN & $95 \% \mathrm{CI}$ & Min. & Max. \\
\hline $\begin{array}{l}\text { Age(years old): } \\
\text { Under } 308(24.2 \%) \\
\text { Between } 30 \text { and } 39.912(36.4 \%) \\
\text { Between } 40 \text { and } 49.98(24.2 \%) \\
50 \text { and over } 5(15.2 \%)\end{array}$ & 38.2 & 35.2 to 41.3 & 26 & 55 \\
\hline Weight ( Kg) & 76.5 & 71.9 to 81.1 & 48.9 & 103.1 \\
\hline Height $(\mathrm{cm})$ & 172.5 & 169.8 to 175.1 & 159 & 184.5 \\
\hline $\begin{array}{l}\text { Body Mass Index }(\mathrm{Kg} / \mathrm{m} 2) \\
\text { - Healthy (18.5to } 24.9): 18(54.5 \%) \\
\text { - Overweight ( } 25.0 \text { to } 29.9): 11(33.3 \%) \\
\text { - Obesity (30 or higher): } 4(12.1 \%)\end{array}$ & 25.7 & 24.3 to 27.1 & 18.8 & 34.2 \\
\hline Systolic blood pressure $\mathrm{mmHg}$ & 129.1 & 124.8 to 133.5 & 103 & 150 \\
\hline Diastolic blood pressure $\mathrm{mmHg}$ & 75.6 & 71.9 to 79.3 & 58 & 99 \\
\hline Total Cholesterol (mg /dl) & 195.6 & 177.8 to 213.3 & 106 & 274 \\
\hline HDL Cholesterol ( mg/ dl) & 50.9 & 43.9 to 58.1 & 27 & 102 \\
\hline Waist circumference $(\mathrm{cm})$ & 86.9 & 83.4 to 90.5 & 72 & 119 \\
\hline Hip circumference $(\mathrm{cm})$ & 92.7 & 89.6 to 95.8 & 73 & 110 \\
\hline
\end{tabular}


as smoking, alcohol and the abuse of other drugs without specifying the type of drug. As for alcohol, a positive answer was considered when inmates reported an abusive consumption before imprisonment and when they acknowledged having a problem with alcohol and not just occasional or social drinking.

A systematic revision of clinical records was performed to obtain data on total cholesterol and HDL cholesterol. The last results were used without considering how old they were, neither the existence of a history of or treatment for conditions such as diabetes, HIV, hypertension or dyslipidemia.

Group sessions: Three one and a half hour long group sessions were held. They dealt with the etiology, diagnosis and treatment of diabetes, hyperlipidemia and hypertension, as well as basic principles on eating, Mediterranean diet and physical exercise in different conditions. In the last session a documentary on healthy eating was played ${ }^{18}$. As a practical activity inmates were asked to build a nutritional pyramid (see Figure 1).

All participants were asked to sign an informed consent form to use the data obtained through the interview and the revision of their clinical records. Authorization from the General Secretariat of Penitentiary Institutions Support Unit was sought with reference to the legal terms included in Circular Or-

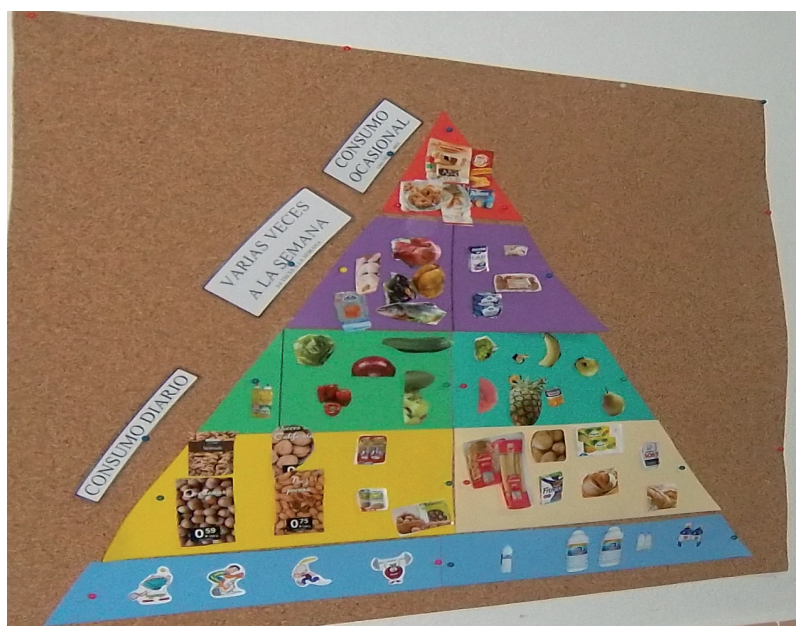

Figure 1: Nutritional pyramid made by the inmates of CP Soria in the Health Education workshop on cardiovascular diseases.

der 7/99 on "Papers, studies and research within prisons". The statistical study was descriptive. Initially the type of distribution that variables followed was checked through the Kolmogorov-Smirnov test and those which followed a normal distribution were expressed as means with their corresponding 95\% confidence intervals. Maximum and minimum values were also expressed. Qualitative variables were shown as absolute and relative frequencies.

Table 3: Sample distribution according to relative risk of comorbidity associated to overweight and the distribution of adipose tissue.

\begin{tabular}{|c|c|c|c|c|c|}
\hline \multirow[b]{3}{*}{ Healthy } & \multirow{3}{*}{$\begin{array}{c}\text { BMI }(\mathrm{kg} / \mathrm{m} 2) \\
18.5-24.9\end{array}$} & \multicolumn{4}{|c|}{$\begin{array}{l}\text { Relative Risk of comorbidity according to WC } \\
\qquad(\mathrm{n}=33)\end{array}$} \\
\hline & & \multicolumn{2}{|c|}{$\mathrm{WC}<102 \mathrm{~cm}$} & \multicolumn{2}{|c|}{$\mathrm{WC}>102 \mathrm{~cm}$} \\
\hline & & None & $16(48.8 \%)$ & $\begin{array}{c}\text { Silghtly } \\
\text { increased }\end{array}$ & $2(6.0 \%)$ \\
\hline Overweight I,II & $\begin{array}{l}25-26.9 \\
27-29.9\end{array}$ & $\begin{array}{l}\text { Slightly } \\
\text { increased }\end{array}$ & $\begin{array}{l}4(12.1 \%) \\
7(21.2 \%)\end{array}$ & Increased & \\
\hline Obesity I & $30-34.9$ & Increased & $4(12.1 \%)$ & High & \\
\hline
\end{tabular}

BMI= Body Mass Index. WC= Waist circumference $(\mathrm{cm})$.

Table 4: Frequency of main variables on toxic habits

\begin{tabular}{ccc}
\hline SUBSTANCE & YES & NO \\
\hline ALCOHOL & $5(15.1 \%)$ & $28(84.8 \%)$ \\
\hline OTHER DRUGS & $10(30.3 \%)$ & $23(69.6 \%)$ \\
\hline SMOKING & $20(60.6 \%)$ & $13(39.3 \%)$ \\
\hline
\end{tabular}


Table 5: Results of the post-intervention survey on knowledge acquired.

\begin{tabular}{|c|c|c|c|}
\hline QUESTIONS: & $\begin{array}{c}\text { RIGHT } \\
\mathrm{n}=17(100 \%)\end{array}$ & $\begin{array}{l}\text { WRONG } \\
\mathrm{n}=17(100 \%)\end{array}$ & $\begin{array}{c}\text { NO } \\
\text { ANSWER } \\
n=17(100 \%)\end{array}$ \\
\hline $\begin{array}{l}\text { 1. Smoking, being overweight and not doing sport are cardiovascular risk } \\
\text { factors } \\
\text { Modifiable/non-modifiable }\end{array}$ & $16(94 \%)$ & 0 & $1(6 \%)$ \\
\hline $\begin{array}{l}\text { 2. As for diabetes, what is the correct statement: The Liver makes little or } \\
\text { no insulin/ The pancreas makes little or no insulin/The Liver makes little } \\
\text { or no glucose }\end{array}$ & $15(88.23 \%)$ & $1(6 \%)$ & $1(6 \%)$ \\
\hline 3. Hypertension is defined as blood pressure under $140 / 90 \mathrm{~T} / \mathrm{F}$ & $9(52.94 \%)$ & $6(35.29 \%)$ & $2(12 \%)$ \\
\hline 4. What is the most beneficial type of cholesterol? HDL / LDL & $10(58.8 \%)$ & $6(35.29 \%)$ & $1(6 \%)$ \\
\hline $\begin{array}{l}\text { 5. Out of the following nutrients, which provide energy? Lipids/Vitamins/ } \\
\text { Carbohydrates }\end{array}$ & $3(17.64 \%)$ & $12(70.58 \%)$ & $2(12 \%)$ \\
\hline 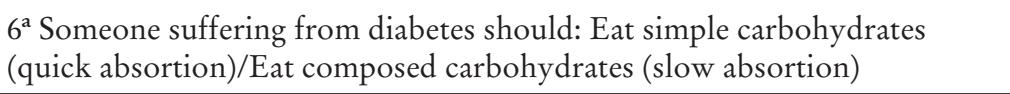 & $12(70.58 \%)$ & $3(17,64 \%)$ & $2(12 \%)$ \\
\hline $\begin{array}{l}\text { 7. Is it good for people with elevated blood pressure to e at food with a lot } \\
\text { of salt? }\end{array}$ & $14(82.35 \%)$ & $2(12 \%)$ & $1(6 \%)$ \\
\hline $\begin{array}{l}\text { 8. What has a lot of cholesterol?: Yema de huevo/Chocolate pie/Pear/Blue } \\
\text { fish }\end{array}$ & $15(88.23 \%)$ & $2(12 \%)$ & 0 \\
\hline $\begin{array}{l}\text { 9. According to the Mediterranean diet we should: Take } 2 \text { to } 3 \text { spoons of } \\
\text { olive oil every day/ Take } 0.51 \text { of olive oil every day/ Take butter instead of } \\
\text { olive oil, every day }\end{array}$ & $15(88.23 \%)$ & $2(12 \%)$ & 0 \\
\hline $\begin{array}{l}\text { 10. To follow a Mediterranean diet we should: Skip breakfast/ Make } 4 \text { to } 5 \\
\text { meals a day/ Eat nothing helps losing weight }\end{array}$ & $15(88,23 \%)$ & $1(6 \%)$ & $1(6 \%)$ \\
\hline 11. What type of meat is healthier? Red meat/White meat & $15(88,23 \%)$ & $1(6 \%)$ & $1(6 \%)$ \\
\hline $\begin{array}{l}\text { 12. According to the Mediterranean diet what type of food should we } \\
\text { take on a daily basis? Fruit/ Eggs/Red meat/ Vegetables/ Muffins/ Dairy } \\
\text { products }\end{array}$ & $16(94 \%)$ & $1(6 \%)$ & 0 \\
\hline $\begin{array}{l}\text { 13. Is it true that we should drink at least } 1.5 \mathrm{~L} \text { of water every day? YES/ } \\
\text { NO }\end{array}$ & $16(94 \%)$ & 0 & $1(6 \%)$ \\
\hline $\begin{array}{l}\text { 14. Why should we do sport? a) Because it helps gain weight, b) Because it } \\
\text { reduces the risk of diabetes, c) Porque sube el ánimo. d) Because it is good } \\
\text { for your heart }\end{array}$ & $14(82.35 \%)$ & $3(17.6 \%)$ & 0 \\
\hline $\begin{array}{l}\text { 15. If I suffer from a chronic disease such as diabetes, hypertension or high } \\
\text { cholesterol, can I do sport? YES/NO }\end{array}$ & $17(100 \%)$ & 0 & 0 \\
\hline $\begin{array}{l}\text { 16. Have you learnt useful contents for your daily life in the health } \\
\text { education workshop? }\end{array}$ & $\begin{array}{c}\text { Little } \\
1(6 \%)\end{array}$ & $\begin{array}{c}\text { Some } \\
6(35.29 \%)\end{array}$ & $\begin{array}{c}\text { A lot } \\
10(58.8 \%)\end{array}$ \\
\hline 17. Did you find interesting the documentary? & $\begin{array}{c}\text { Yes } 12 \\
(70.58 \%)\end{array}$ & No & $\begin{array}{l}\text { No answer } \\
5(29.41 \%)\end{array}$ \\
\hline 18. How did you find the number of sessions? & $\begin{array}{c}\text { Few } \\
3(17.6 \%)\end{array}$ & $\begin{array}{c}\text { Enough } \\
13(76.4 \%)\end{array}$ & $\begin{array}{l}\text { Too many } \\
1(6 \%)\end{array}$ \\
\hline $\begin{array}{l}\text { 19. Do you think that the people who gave the lectures have enough } \\
\text { training on the matter? }\end{array}$ & $\begin{array}{c}\text { YES } \\
16(94 \%)\end{array}$ & $\mathrm{NO}$ & $\begin{array}{l}\text { No answer } \\
1(6 \%)\end{array}$ \\
\hline 20. How did you find the activities in the workshop? & Boring & Of Little use & $\begin{array}{l}\text { Interesting } \\
17(100 \%)\end{array}$ \\
\hline
\end{tabular}




\section{RESULTS}

33 inmates requested to participate in the workshop $(21 \%$ of the total population hosted in the facility), out of which 32 attended the first session, 26 the second and 18 the third. All participants were male. The sample's mean age was 38.2 years ranged between 26 and 55.18 were over 35 . The anthropometric assessment was carried out on all 33 inmates who requested participation. The results of such assessment: age, height, weight, BMI, waist and hip circumferences as well as blood pressure total and HDL cholesterol are depicted in Table 2. The assessment of the relative risk of comorbidity between obesity and distribution of body fat is depicted in Table 3. In the $18(54 \%)$ participants who were over 35 years old, cardiovascular risk could be calculated by means of the REGICOR table, obtaining that $4.12 \%$ were at a moderate risk (5 to $9.9 \%$ ) of suffering a cardiovascular disease throughout the next ten years ${ }^{19}$. Toxic habits are depicted as frequencies of qualitative variables in Table 4. Eight (24\%) participants were undergoing treatment for hypertension, three $(9 \%)$ for high cholesterol and five (15\%) for diabetes: two with insulin and the remaining three with oral anti-diabetic drugs. Only one of the participants presented HIV antibodies. The last session survey was answered by seventeen $(51 \%)$ participants and the results are shown in Table 5. Some of them reported having initiated changes in their lifestyles, among them: daily consumption of fruit, eating less or eating the food offered by the facility without buying more at the commissary and doing more sport or quitting smoking.

\section{DISCUSSION /CONCLUSIONS}

Health Education has proved useful in improving lifestyle-related parameters, yet it is not clear whether group interventions entail better outcomes than individual interventions. Furthermore, it has been confirmed that health education interventions need to be structures, planned and sequentially developed ${ }^{20}$. Our main objective was to enhance knowledge on cardiovascular diseases and to modify unhealthy lifestyles. Ass to evaluate the changes undergone by inmates we should have re-interviewed participants at least six months after the intervention. Unfortunately we have not been able to do so; we only have the intention of some participants to modify determined behaviors. The project arises from the growing demand during nursing consultation periods for information on health issues concer- ning overweight, diabetes and hypertension. It was only later that we thought that the results might be of interest to other professionals. This is the main reason why the study is only descriptive and it does not prove the efficacy of health education interventions beyond the authors' and participants' opinions and impressions. The sample is small and results are therefore not generalizable although the anthropometric assessment shows the trend- already pointed out by other studies- of the imprisoned population suffering too the major $21^{\text {st }}$ century epidemic: obesity. Different scales and indexes have been used in assessing the relative risk of suffering a cardiovascular event, yet different results have been concluded, This proves, as other studies have already pointed out too, that for every scale or index, there are different results: a point on which there is no agreed consensus between medical associations ${ }^{21}$. Calculation of cardiovascular risk should only serve as a means to implement preventive measures addressing such parameters. Therefore, the results should always be considered for guidance only. Another weakness that we have faced, and that we should obviously improve, is the development of the final questionnaire, since there have been questions which inmates found very difficult to correctly answer. Nevertheless, we consider that we have fulfilled our initial objective, which was no other than to encourage healthy lifestyles. On the other hand, this project is also used to develop other roles of prison nursing staff (teaching and research) since it can serve as an example both for nursing students and other professionals to be acquainted with the potential of prison nursing. Prison nursing staff has the duty to include health education strategies in their everyday tasks as a key element of such. This should address the modification of unhealthy habits, especially by encouraging healthy eating and physical activity.

\section{CORRESPONDENCE}

Mercedes Martínez-Delgado

Centro Penitenciario de Soria.

Email: mmercedestorlengua@hotmail.com

\section{BIBLIOGRAPHY}

1. Palmar Santos AM. Métodos educativos en salud. Barcelona: Elsevier; 2014.

2. Rueda JR, Manzano I, Darío R, Pérez de Arriba J, Zuazagoitia J, Zulueta G. La promoción de la salud. Algunas teorías y herramientas para la plani- 
ficación y evaluación de intervenciones sobre los estilos de vida. Investigación Comisionada. Vitoria Gasteiz: Departamento de Sanidad, Gobierno Vasco; 2008.

3. Gutiérrez-García JJ. Grupo de trabajo de promoción en formación y educación para la salud. Formación en promoción y educación para la salud. Madrid: Ministerio de Sanidad; 2013.

4. Pérez Jarauta MJ, Echauri Ozcoidi M, Ancizu Irue E, Chocarro San Martin J. Manual de educación para la Salud. Navarra: Gobierno de Navarra, Instituto de Salud Pública; 2006.

5. Sociedad Española para el Estudio de la Obesidad. Consenso SEEDO 2007 para el sobrepeso y la obesidad y el establecimiento de criterios de intervención terapéutica. Rev.Esp.de Obesidad. 2007 Mar: 7-48.

6. Vera-Remartínez EJ, Borraz-Fernández JR, Domínguez Zamorano JA, Mora Parra LM, Casado Hoces SV, González Gómez JA, et al. GESESP Grupo de enfermería sociedad española de sanidad penitenciaria, Prevalencia de enfermedades crónicas y factores de riesgo en población penitenciaria española. Rev. Esp Sanid Penit; 2014; 16 (2): $38-47$.

7. Mortalidad en Instituciones Penitenciarias 2013. Madrid: Ministerio del Interior. Secretaria General de Instituciones Penitenciarias. Subdirección General de Coordinación de Sanidad penitenciaria; 2014.

8. Martínez Delgado MM, Espeleta Cabrejas N. Valoración del riesgo cardiovascular en un grupo de pacientes participantes en un taller de nutrición. Rev. Esp Sanid Penit. 2014; Supl 16: 75.

9. Garcés E, Casado SV, Armenteros B, Blanco A, Borraz JR, Vera-Remartínez EJ, et al. Riesgo cardiovascular en las prisiones españolas. Rev. Esp Sanid Penit. 2014; Supl 16: 73.

10. Córdoba R, Cabezas C, Camarelles F, Gómez J, Díaz Herranz D, López A. Grupo de Educación Sanitaria y Promoción de la Salud PAPPS, Recomendaciones sobre el estilo de Vida. Aten Prima. 2012; 44 sup. 1: 16-22.

11. Gil Delgado Y, Domínguez Zamorano JA, Martínez Sánchez Suárez E. Valoración de los beneficios para la salud conseguidos mediante un programa de nutrición dirigido internos con factores de riesgo cardiovascular del centro penitenciario de Huelva. Rev. Esp Sanid Penit. 2011; 3 (13): 75-83.
12. Montalbán Sánchez. Índice Cintura/Cadera, Obesidad y Estimación del riesgo cardiovascular en un centro de salud de Málaga. Med de Fam. 2001; 3 (2): 14- 21.

13. Martin Castellanos A, Barca FJ, Cabañas MD, Martin P, García M, Muñoz MA, et al. Obesidad e indicadores antropométricos en una muestra de varones con Síndrome Coronario Agudo, en un Área de Salud que incluye reclusos: estudio casocontrol. Rev. Esp Sanid Penit. 2015; 1 (17): 20-9.

14. Gerencia Regional de Salud, Junta de Castilla y León. Guía práctica basada en la evidencia de Valoración y tratamiento del Riesgo Cardiovascular. Valladolid: Gerencia Regional de Salud; 2008.

15. Organización Panamericana de Salud. Prevención de las enfermedades cardiovasculares. Directrices para la valoración y el manejo del riesgo cardiovascular. Geneva: Word Health Organization; 2007.

16. Sans S, Fitzgerald AP, Royo D, Conroy R, Graham L. Calibración de la tabla SCORE de Riesgo cardiovascular para España. Rev. Esp. Cardiol. 2007; 60(5): 476-85.

17. Armenteros B, Blanco A, Borraz JR, Domínguez JA, Garcés E, González-Gómez JA, et al. Enfermería Penitenciaria: Competencias, funciones e intervenciones. Madrid: Sociedad Española de Sanidad Penitenciaria; 2010.

18. Ferrer E, Gallego J. Cine y Salud, SUPER SIZE ME .Guía didáctica para el profesorado [Internet]. Zaragoza: Gobierno de Aragón; 2013 [citado 2015 feb 04]. Disponible en: http: //www.aragon. es/estaticos/Import Files/09/docs/profesionales/ Salud\%20publica/Documentacion/Catalogo $\% 20$ pub\% 20general\%20salud $\% 20$ enlaces $\% 20$ public/Programa \%20y\%20salud/Alimentacion/ GPROFE+\% E2\% 80\% A2+SUPERSIZE.PDF.

19. Tablas para el Cálculo del Riesgo Coronario a diez años. Adaptación de las Tablas de Framinghan a la población español: prevención primaria de la enfermedad coronaria. Barcelona: Generalitat de Catalunya. Departament de Salut; 2012.

20. Cerrillo Patiño J. La educación grupal a pacientes diabéticos tipo 2 mejora los conocimientos de la enfermedad, el control metabólico y factores de riesgo cardiovascular. Evidentia. 2006 nov-dic; 3 (12).

21. Álvarez Cosme A. Las tablas de riesgo cardiovascular. Una revisión crítica. Medifan. 2001; 11 (3): 122-139. 